\section{Big gains for biology and IT in Japanese science budget}

Tokyo

Japan will spend a record amount on science and technology in the next fiscal year, thanks to the nation's largest-ever budget. The budget, approved by the Cabinet on 24 December, includes big increases in support for the life sciences and information technology.

In the financial year 2000, beginning on 1 April, government ministries will have $¥ 1.2$ trillion (US $\$ 11.8$ billion) to spend on research, a rise of 6.8 per cent.

The increase is largely the result of funding for prime minister Keizo Obuchi's Millennium Project, launched last year to promote industries in areas such as biotechnology, information sciences and the environment (see Nature 401, 3; 1999).

These projects account for roughly 10 per cent of the new spending, of which $¥ 64$ billion is allocated to research on human and rice genomes. The rest will be spent on the development of high-speed Internet services and environmental technology.

The total government budget will grow by 3.8 per cent to $¥ 84.9$ trillion. Despite a pledge to target areas such as economic structural reform and environmental planning, the budget is still dominated by large public-works projects.

The budget has been criticized for its heavy reliance on government bonds; the national debt is expected to grow to $¥ 645$ trillion by next year, 1.3 times the country's gross domestic product.

Although many have welcomed the support for science and technology, an official from the Science and Technology Agency (STA) says that the budget "is bad news for tax payers", as the overall increase in the agency's budget, at 0.8 per cent, is relatively modest compared to past increases.

Spending on genome research, however, will grow by almost 50 per cent, to $¥ 17.6$ billion. Of this, $¥ 10$ billion will go to the Genome Sciences Centre at the Institute of Physical and Chemical Research (RIKEN), and $¥ 1.9$ billion towards setting up a centre for medical research on single-nucleotide polymorphisms.

A planned national centre for regenerative medicine, which would do research on the development, differentiation and regeneration of plant and animal cells, will also get $¥ 61$ billion for building its facilities.

In contrast, the budgets for space development and nuclear research will be cut by 8.9 per cent and 3.9 per cent, respectively. Last year's failed launch of the H-II rocket (see Nature 402, 336; 1999) caused the government to abandon the H-II programme
Japan's science and technology budget

fiscal year 2000 (in billion yen; US\$1 = ¥103)

Science and Technology Agency

\begin{tabular}{|c|c|c|}
\hline & Budget & Change from 1999 \\
\hline Total budget & 780.3 & $+0.8 \%$ \\
\hline Genome research & 17.6 & $+47.9 \%$ \\
\hline Brain research & 20.1 & $+9.8 \%$ \\
\hline Space development & 170.6 & $-8.9 \%$ \\
\hline $\begin{array}{l}\text { Nuclear energy } \\
\text { (including nuclear sa }\end{array}$ & 257.4 & $-3.9 \%$ \\
\hline
\end{tabular}

Ministry of International Trade and Industry

\begin{tabular}{|c|c|c|}
\hline Total R\&D budget & 528.3 & $+4.4 \%$ \\
\hline Biotechnology & 10.3 & New \\
\hline $\begin{array}{l}\text { Information } \\
\text { technology }\end{array}$ & 10.4 & $\mathrm{New}$ \\
\hline 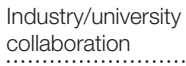 & 16.9 & $+100 \%$ \\
\hline Nuclear safety & 127.8 & $+22.9 \%$ \\
\hline
\end{tabular}

Ministry of Education, Science,

Sports and Culture

Grants-in-aid for

scientific research $\quad 141.9+8.0 \%$

Joint research with

............................

Postdoctoral

fellowships

120.9

Promotion of

biological sciences

Centre of excellence

programme

17.9

.............

42.9

70.2

and focus on the H-IIA rocket, for which it has allocated $¥ 52$ billion in the 2000 budget.

Support for start-up companies and businesses spun-off from research, particularly from universities, also features strongly in the budget. The STA, the Ministry of Education, Science, Sports and Culture (Monbusho) and the Ministry of International Trade and Industry (MITI) will all increase support for collaborations between industry, government research institutes and universities.

Monbusho's postdoctoral fellowship scheme, which reached its target of increasing the ranks of Japan's postdoctoral researchers to 10,000 by this year, will support an additional 400 postdocs with the STA.

The fellowship scheme has been criticized for increasing the number of postdoctoral researchers without creating the research posts to accommodate them. But MITI hopes to promote collaboration between young researchers and venture businesses.

MITI's budget includes money for the analysis of human and microbial genomes, bioinformatics and the analysis of protein structure and function.

The ministry will also receive money for nuclear safety, including the regulation of high-level nuclear waste.

Asako Saegusa

๙๑ 2000 Macmillan Magazines Ltd
Genomics companies boom on New York stock exchange

\section{Washington}

A clutch of US biotech companies with genomics-based business plans saw their stock prices rise dramatically in heavy trading in the final weeks of December. Some reached almost ten times their initial value.

According to biotech analyst Steven Burrill of San Francisco, the rise is the result of a "confluence" of factors including the completion of human chromosome 22 , the sequencing of the first billion base pairs of the human genome and the impending completion of the Drosophila genome.

Celera Genomics Inc., which is competing with the international Human Genome Project to sequence the human genome, rose to $\$ 186$ a share by the beginning of this week, more than three times its price at the beginning of December.

Paul Boni, an analyst with Punk, Ziegel and Co. in New York, suggests that the sequencing race may have helped to raise both Celera's profile and its price. "Who wins this race is largely irrelevant," he says, adding that it has boosted the fortunes of other genomics database companies. Incyte Pharmaceuticals Inc., of Palo Alto, California, has seen its price climb from $\$ 12$ a share in November to $\$ 89$ by 3 January.

David Gardner, co-founder of 'The Motley Fool', an online investmentstrategies site, says that the addition of Celera's stock to their portfolio - the site purchased the stock at $\$ 79$ in midDecember - was "an obvious catalyst" in its rise.

Eric Schmidt, a biotech analyst with SG Cowen Securities in New York, says that Pfizer's decision in November to subscribe to genome databases owned by Celera and Incyte could also have triggered the increase.

Schmidt points out that Celera and Incyte differ from traditional biotech companies in that their futures do not depend on getting a compound through clinical trials, but on supplying the "picks and shovels" for gene prospecting.

Several companies that use genomics to develop potential tests or therapies have also done well. These include Human Genome Sciences Inc. of Rockville, Maryland, whose shares rose from around $\$ 40$ in August to almost $\$ 145$ last week. For long-term success, however, "they will have to come up with a blockbuster", says Schmidt. Paul Smaglik 